\title{
Polyribosome Profiling
}

Wei Zheng*

Keck Biotech Services, Yale University, New Haven, USA

*For correspondence: wei.zheng.madison@gmail.com

\section{Materials and Reagents}

1. Acetone

2. Sucrose

3. Cyclohexamide

4. Bromophenol blue (BPB)

5. Urea

6. Tris- $\mathrm{HCl}$

7. Tris-Acetate

8. $\mathrm{MgCl}_{2}$

9. DTT

10. $\mathrm{NH}_{4} \mathrm{Cl}$

11. $\mathrm{NaCl}$

12. DEPC-treated water

13. Heparin

14. Stocks (see Recipes)

15. Lysis buffer (see Recipes)

16. $60 \%$ sucrose (see Recipes)

17. $7 \%$ sucrose solution (see Recipes)

18. $47 \%$ sucrose solution (see Recipes)

19. Diluted sucrose (see Recipes)

20. Cyclohexamide to add to cells (see Recipes)

\section{Equipment}

1. Autoclaved, RNase free $500 \mathrm{ml}$ centrifuge bottles (1 per sample)

2. Autoclaved, RNase free $40 \mathrm{ml}$ centrifuge bottles (1 per sample)

3. Centrifuges

4. Colored Epi tubes. Need 30/sample

5. $15 \mathrm{ml}, 50 \mathrm{ml}$ falcon tubes (BD Biosciences, Falcon ${ }^{\circledR}$ ) 
6. Ultracentrifuge tubes (Don't autoclave) (Beckman Coulter, catalog number: 344059)

7. Beckman JA-10, JA-20, and Epi rotors to $4{ }^{\circ} \mathrm{C}$ (Beckman Coulter)

8. Ultra SW-51 buckets to $4{ }^{\circ} \mathrm{C}$

9. RNase-free glass beads and bead scoop

10. Foxy fraction collector

11. BioRad Econo UV monitor (Bio-Rad)

12. Peristaltic pump

\section{Procedure}

Day 1

1. Make sure all stock solutions are previously prepared.

2. Inoculate an overnight yeast cell culture from fresh plates.

Day 2

1. Get together all the necessary equipment prior to starting as this is a time-sensitive experiment.

2. Aliquot acetone - if you are harvesting protein pellets.

a. 7 parts acetone to 2 parts water.

b. Aliquot $0.9 \mathrm{ml}$ into colored Eppendorf tubes. Label 1-24, P \& C. Store at $-20{ }^{\circ} \mathrm{C}$.

3. Pour gradients

a. Make sucrose solutions and dilutions.

b. Into $15 \mathrm{ml}$ Beckman tubes, add $2.4 \mathrm{ml}(3 \times 800 \mu \mathrm{l})$ of $47 \%$ sucrose solution to tube.

C. Freeze at $-80{ }^{\circ} \mathrm{C}$ for $30 \mathrm{~min}$.

d. Carefully add $37 \%$ same way. Do this carefully. Don't want dimples.

e. Repeat with $27 \%$ and $17 \%$.

f. Add $800 \mu \mathrm{l} 7 \%$ gradient 2 times. Add $600 \mu \mathrm{l} 7 \%$ solution to very top of tube (add as much as possible).

g. Freeze $2-3 \mathrm{~h}$. Transfer to fridge that will not be disturbed and thaw $\mathrm{O} / \mathrm{N}$.

4. Inoculate $100 \mathrm{ml}$ of media with $\mathrm{O} / \mathrm{N}$.

5. Put JA-10 rotor in Beckman. Leave at $4{ }^{\circ} \mathrm{C}$. Move JA-20 and Epi rotors to fridge.

6. Put ultracentrifuge baskets in fridge.

Day 3

A. Cell extraction

1. Take OD of culture. Want between 0.4-0.6.

2. Get 2 buckets of ice, turn on Marathon to cool down. 
3. Make lysis buffer and weigh out cyclohexamide.

4. Pour culture into $500 \mathrm{ml}$ centrifuge bottle containing cyclohexamide. Swirl for $30 \mathrm{sec}$. and fill $3 / 4$ full with ice.

5. Balance tubes and centrifuge in JA-IO $7 \mathrm{k}$ for $5 \mathrm{~min}$ ( $5 \mathrm{~min}$ from beginning of spin-not to when it gets up to speed). Dump ice and cells out aggressively.

6. Resuspend cells in $20 \mathrm{ml}$ cold lysis buffer (do NOT throw away remaining lysis buffer -store on ice). Transfer to $40 \mathrm{ml}$ centrifuge tube and spin at $7 \mathrm{~K}$ for $3 \mathrm{~min}$. This step is very time sensitive. Balance as fast as possible.

7. Resuspend pellet in remaining liquid. Measure and bring volume up to $600 \mu \mathrm{l}$ with lysis buffer in colored Epi tube. A vigorous dumping will leave about $600 \mu \mathrm{l}$.

8. Add glass beads.

9. Vortex in cold room for $3 \mathrm{~min}$.

10. Puncture hole in bottom. Stuff on another tube. Put whole thing in $50 \mathrm{ml}$ Falcon, spin in Marathon 2 min at $5 \mathrm{~K}$.

11. Transfer supernatant to new tube. Centrifuge at $7 \mathrm{~K}$ in the JA-18 Eppendorf tube rotor in Beckman for 10 min.

12. Transfer supernatant to Eppendorf tube.

13. Start precooling ultracent - turn on, set to $4^{\circ} \mathrm{C}$, pull vacuum. Get rotor out.

B. Quantitate RNA

1. Spec $5 \mu \mathrm{l}$ of RNA in $995 \mu \mathrm{l}$ water at UV $260 \mathrm{~nm}$.

2. Calculate volume of extract to load onto gradients: $\mu$ l loaded $=10$ OD units $* 1,000 \mu \mathrm{ml}^{-1} /$ $\left(\mathrm{OD}_{260}\right.$ * dilution factor).

3. Set aside $1 / 24^{\text {th }}$ of volume that will be loaded onto gradients for control.

C. Ultracentrifuging

1. Load 10 OD units of sup on top of gradient by dropping gently onto top.

2. Grease all baskets with SPINKOTE for rotor SW-41. Line up in pairs: $1 \& 4,2 \& 5,3 \& 6$.

3. Load tubes into baskets. Write down who went where.

4. Hang baskets onto rotor. Give a little wiggle to make sure they are on securely.

5. Spin at $39 \mathrm{~K}$ for $2.5 \mathrm{~h}$ at $4{ }^{\circ} \mathrm{C}$. Decel $=7$. This breaks until $\mathrm{RPM}=2,000$. Once that hits, it stays on hold until you stop it (by hitting stop). Takes approximately 4 min to come down.

D. Collecting fractions

1. While samples are centrifuging, make $7 \%$ sucrose $\& 60 \%$ sucrose + BPB.

a. $7 \%$ sucrose solution for baselining $\sim 50 \mathrm{ml}$.

b. $60 \%$ sucrose $+100 \mu \mathrm{l} 5 \mathrm{mg} / \mathrm{ml}$ bromophenol blue $+100 \mu \mathrm{l}$ DEPC $\sim 50 \mathrm{ml}$. 
2. Turn on reader about $20 \mathrm{~min}$ before the end of the spin.

3. Once the reader is warmed up, baseline reader:

a. Turn top of reader to Max Open, sensitivity $=1$, noise filter $=1.5$. Filter $=5 \mathrm{~mm}$ path length, 2 filters. Both need to be same setting (one that reads, one that is a reference).

b. Turn on pump (not foxy). Fill spill tube with $7 \%$ solution. Run $7 \%$ through so drips out the fraction collector.

c. Click "autobaseline" and move pen to position 50 on paper.

d. Once $7 \%$ is moving through reader, move pen manually down to position 20 on chart. Want consistent, straight line.

e. Turn off paper, move pen up off of paper.

f. Take out $7 \%$ and run dry for a while to get rid of droplets in thin tubing going to fraction collector. Very important to get this dry.

g. Wipe down seals with D.D. water.

h. Get blue sucrose moving though large tubing through to metal tube. Once starts dripping, stop pump and wipe off blue drop.

i. Pump set at $80 \times 10$. Turn on fraction collector first, then turn on pump - now foxy controls the pump.

j. Foxy program: $E=e d i t$, simple rack, last $=24$, collect by drops $=10$.

k. Program \#2.

4. Load acetone tubes onto collector.

5. When spin is done, take out baskets. If doing more than 2 gradients, store holder in fridge. If only doing two, move holder to bench top. Wipe down rotor and put away.

6. Take tube out of basket with forcepts. Assemble white seal on top of tube and attach to pump.

7. Start chart at 60 or $\mathbf{1 5 0}$ (write down speed). Move pen on paper!

8. On Foxy, hit run - fraction collector will move.

9. Time between time that measurement is taken (the pen will mark all the way up) and when you see first drop into tube. Write down.

10. When done, turn off foxy, reverse flow on pump until get the Beckman tube about $1 / 2$ full of blue dye.

11. Dump off blue sucrose and invert tube. Pellet is at the bottom. Add $500 \mu$ lysis buffers to pellet and resuspend by vortexing hard. Transfer to Epi tube with acetone marked "P". Add $500 \mu$ lysis buffer to $1 / 24^{\text {th }}$ sample saved on ice before spinning. Transfer to Epi tube with acetone marked " $\mathrm{C}$ ".

12. Put all samples in $-20^{\circ} \mathrm{C} \mathrm{O} / \mathrm{N}$.

13. Clean tube holder and run thin tubing to Foxy dry. Must have no droplet. If there is any problem run $7 \%$ through and repeat process with blue. 
14. To clean system run $250 \mathrm{ml}$ D.D. water +2 drops Ivory Soap through to fraction collector and rinse with $2 \times 250 \mathrm{ml}$ of D.D. water.

Day 4

A. Precipitating samples

1. Centrifuge acetone samples $5 \mathrm{~min}$ at full speed $4{ }^{\circ} \mathrm{C}$. Aspirate sup - pellets may not be visible.

2. Dry covered to prevent dust from going into tube $\sim 10 \mathrm{~min}$ or until there is no more acetone fumes. Can save dry pellets in $-20^{\circ} \mathrm{C}$ until use.

B. Preparing for westerns

1. Resuspend pellets in $10 \mu \mathrm{l}$ loading buffer by flicking tube.

2. Boil 2-3 min, vortex, quick spin.

3. Load onto gel (do not load insoluble pellet).

4. Loading buffer - for protein detection. 3 parts $6 \mathrm{M}$ urea to 1 part $4 \times$ Laemmli buffer.

\section{$\underline{\text { Recipes }}$}

1. Stocks

$1 \mathrm{M}$ Tris- $\mathrm{HCl}\left(\mathrm{pH} 7.5\right.$ at $\left.4{ }^{\circ} \mathrm{C}\right)$

$1 \mathrm{M}$ Tris-Acetate $\left(\mathrm{pH} 7.0\right.$ at $\left.4{ }^{\circ} \mathrm{C}\right)$

$1 \mathrm{M} \mathrm{MgCl}_{2}$

$1 \mathrm{M} \mathrm{DTT}$ (store at $-20^{\circ} \mathrm{C}$ )

$1 \mathrm{M} \mathrm{NH}_{4} \mathrm{Cl}$ - do not autoclave.

2. Lysis buffer

$10 \mathrm{mM}$ Tris- $\mathrm{HCl}\left(\mathrm{pH} 7.5\right.$ at $\left.4{ }^{\circ} \mathrm{C}\right)$

$0.1 \mathrm{M} \mathrm{NaCl}$

$30 \mathrm{mM} \mathrm{MgCl} 2$

Filter sterilize, store at RT.

3. $60 \%$ sucrose

Make $60 \%$ sucrose in DEPC-treated water. Use baked spatulas and baked glassware.

Filter sterilize and store at RT.

4. $7 \%$ sucrose solution $(200 \mathrm{ml}$ ) (enough for 4 samples)

$23.3 \mathrm{ml} \quad 60 \%$ sucrose, $7 \%$

$10 \mathrm{ml} \quad 1 \mathrm{M}$ Tris-Acetate, $50 \mathrm{mM}$

$10 \mathrm{ml} \quad 1 \mathrm{M} \mathrm{NH}_{4} \mathrm{Cl}, 50 \mathrm{mM}$

$2.4 \mathrm{ml} \quad 1 \mathrm{M} \mathrm{MgCl}_{2}, 12 \mathrm{mM}$

$0.2 \mathrm{ml} \quad 1 \mathrm{M} \mathrm{DTT}, 1 \mathrm{mM}$ 
$0.2 \mathrm{ml} \quad$ DEPC, $0.1 \%$

Up to volume with DEPC-treated water

5. $47 \%$ sucrose solution $(200 \mathrm{ml})$

$156.7 \mathrm{ml} \quad 60 \%$ sucrose, $7 \%$

$10 \mathrm{ml} \quad 1 \mathrm{M}$ Tris-Acetate, $50 \mathrm{mM}$

$10 \mathrm{ml} \quad 1 \mathrm{M} \mathrm{NH} 4 \mathrm{Cl}, 50 \mathrm{mM}$

$2.4 \mathrm{ml} \quad 1 \mathrm{M} \mathrm{MgCl}_{2}, 12 \mathrm{mM}$

$0.2 \mathrm{ml} \quad 1 \mathrm{MDTT}, 1 \mathrm{mM}$

$0.2 \mathrm{ml} \quad$ DEPC, $0.1 \%$

Up to volume with DEPC-treated water

6. Diluted sucrose $(12 \mathrm{ml})$

$37 \%=9 \mathrm{ml} 47 \%+3 \mathrm{ml} 7 \%$

$27 \%=6 \mathrm{ml} 47 \%+6 \mathrm{ml} 7 \%$

$17 \%=3 \mathrm{ml} 47 \%+9 \mathrm{ml} 7 \%$

7. Cyclohexamide to add to cells (assuming cell volume $=100 \mathrm{ml}$ )

$5 \mathrm{mg}$ cyclohexamide resuspended in water, $50 \mu \mathrm{g} / \mathrm{ml}$

8. Lysis buffer (make $25 \mathrm{ml}$ per sample)

$1.25 \mathrm{mg} \quad$ cyclohexamide, resuspend in water, $50 \mu \mathrm{g} / \mathrm{ml}$

$5 \mathrm{mg}$ heparin, resuspend in water, $200 \mu \mathrm{g} / \mathrm{ml}$

$50 \mu \mathrm{l} \quad$ DEPC, $0.2 \%$

\section{References}

1. Baim, S. B., Pietras, D. F., Eustice, D. C. and Sherman, F. (1985). A mutation allowing an mRNA secondary structure diminishes translation of Saccharomyces cerevisiae iso-1-cytochrome c. Mol Cell Biol 5(8): 1839-1846. 